\title{
NATIONAL SECURITY \\ AND THE PUBLIC'S RIGHT TO KNOW: \\ A NEW ROLE FOR THE COURTS \\ UNDER THE FREEDOM OF INFORMATION ACT
}

For almost two centuries the executive branch of the Government has invoked "national security"1 as a justification for barring public access to government documents. ${ }^{2}$ In many cases, the invocation has been for legitimate reasons. Few would challenge the wisdom or necessity of restricting access to documents when the national security is truly jeopardized, as for example, when the confidentiality of ongoing international negotiations or foreign intelligence operations is imperiled.

Recent years, however, have seen a new and dangerous use for the national security label: to provide a cover for politically embarrassing and sometimes illegal government activities. The transcripts of White House conversations taped during the Nixon Administration provide a vivid example. By the middle of March 1973, President Nixon realized that testimony at the Los Angeles trial of Daniel Ellsberg would inevitably reveal that White House agents had rifled confidential files in the office of Ellsberg's psychiatrist. At a March 17 meeting, the President asked H.R. Haldeman, his Chief of Staff, and John Dean, his counsel, for advice on how to justify the incident. "You might

1 "National security" is a term used frequently by Congress, the courts, and the President, but it is never clearly defined. Generally its meaning encompasses national defense and foreign policy issues. While national defense is widely understood to include the protection of military secrets, foreign policy is a considerably broader concept. It may or may not include international relations-that is, the day-to-day diplomatic interaction among nations.

In the Freedom of Information Act, 5 U.S.C. $\$ 552$ (1970), as amended, Pub. L. 93-502 (Nov. 21, 1974), 88 Stat. 1561 (1974 U.S. Code Cong. \& Ad. News 5758), Congress refers to "national defense or foreign policy." The President used the language "national defense or foreign relations" in the most recent executive order on national security classification. Exec. Order No. 11,652, 3 C.F.R. 339 (1974). The courts tend not to distinguish between the components of national security, preferring to treat them under the general heading of "national security" or "foreign affairs." The subtle differences among interpretations of "national security" are immaterial for purposes of this Comment. Unless specifically noted, the term "national security" will include national defense and foreign policy concerns.

${ }^{2}$ For a general discussion of the history of national security claims, see FOREIGN affairs Division, Legislative Reference Service, Library of Congress, 92d Cong., ist Sess., Security Classification as a Problem in the Congressional Role in Foreign Policy 1-4 (Comm. Print 1971) [hereinafter cited as Security Classification]. 
put it on a national security grounds basis," Dean answered. The President apparently liked the suggestion and worked out the "scenario" with his two advisors:

$\mathrm{P}$-National Security. We had to get information for national security grounds.

$\mathrm{D}$-Then the question is, why didn't the CIA do it or why didn't the FBI do it?

$\mathrm{P}-$ Because we had to do it on a confidential basis.

$\mathrm{H}-$ Because we were checking them.

$\mathrm{P}-$ Neither could be trusted.

D-I think we could get by on that. ${ }^{3}$

Thus it was agreed that the "national security" label would be used to cloak the government's illegal spying activities. Had the pressures of continuing investigation of presidential conduct not forced disclosure of the details of the burglary, the public would never have learned the relevant information.

To guard against excessive government secrecy, Congress enacted the Freedom of Information Act $^{4}$ (FOIA) in 1966. The Act is the first comprehensive attempt to promote public access to government documents. It requires that all agency ${ }^{5}$ records, except those specifically exempted in subsection (b) of the Act, ${ }^{6}$ be made available to any interested member of the public who requests them, as long as the request complies with published rules of procedure. If an agency denies a request for documents, the Act authorizes a disappointed person to bring suit in federal court to compel release of the material sought. Although the FOIA explicitly calls for review de novo of executive decisions to

${ }^{3}$ Submission of Recorded Presidential Conversations to the Comm. on the Judictary of the House of Representatives by President Richard M. Nixon 221 (April 30, 1974).

45 U.S.C. § $552(1970)$.

5 Although the meaning of the term "agency" under the FOIA was subject to some dispute, see Soucie v. David, 448 F.2 1067 (D.C. Cir. 1971), the recent amendments to the Act clarify the scope of the term. "Agency" includes any executive department, government corporation, or other establishment in the executive branch, including the Executive Office of the President, or any independent regulatory agency. "Agency" does not include the President or his immediate personal staff. Pub. L. No. 93-502 (Nov. 21, 1974), 88 Stat. 1561 (1974 U.S. Code ConG. \& AD. NEws 5758), amending 5 U.S.C. § 552 (1970).

${ }^{6} 5$ U.S.C. $\$ 552$ (b) (1970) provides for nine exemptions to the FOIA. The exemptions encompass (1) national security matters, (2) internal personnel rules and practices, (3) statutory exemptions, (4) trade secrets, (5) inter-agency memoranda, (6) matters of personal privacy, (7) investigatory files, (8) financial institution records, and (9) geological information concerning wells. 
withhold documents, courts had decided, before the 1974 amendments became effective, that they were powerless to review national security classifications. If the President had ordered a document relating to the Ellsberg case classified without offering any explanation or justification, the decision would not have been subject to full judicial scrutiny.

By 1974, Congress recognized the failure of the FOIA to prevent improper withholding of information by the Government. Responding to pressures created by the Watergate drama ${ }^{7}$ and to its own sense of the FOIA's inadequacies, ${ }^{8}$ last year Congress overrode a presidential veto and enacted amendments designed to close the Act's loopholes and to direct the courts to play a more decisive enforcement role.

This Comment will explore the scope of the courts' newly authorized powers under the FOIA amendments; the probable judicial response to this authorization, given the judiciary's traditional reluctance to intervene in the conduct of foreign affairs; and the need for a tempering of that reluctance in the interests of a vigorous, open, and democratic polity. ${ }^{9}$

\section{The Scope of Judicial Review of Classified DOCUMENTS}

\section{A. The Development of Public Access}

Until enactment of the FOIA, the public's right of access to government documents depended almost completely on the discretion of the executive branch. Executive departments were authorized to withhold documents they believed to be sensitive. Members of the public could not object to any executive decision.

' 120 CoNG. REc. $S 19806$ (daily ed. Nov. 21, 1974) (remarks of Senator Kennedy).

${ }^{8}$ Hearings on H.R. 5425 and H.R. 4960 Before the Subcomm. on Foreign Operations and Government Information of the House Comm. on Government Operations, 93d Cong., 1st Sess. 25 (1973) [hereinafter cited as House Hearings].

${ }^{9}$ Several of the exemptions provided for in the amendments may have some bearing on national security litigation under the FOIA. The (b)(3) exemption, for example, which exempts all material specifically exempted by statute, will be relied upon in suits challenging the withholding of documents by the Central Intelligence Agency. Similarly, the (b)(7) "investigatory file" exemption may be relevant in cases in which law enforcement and national security interests overlap. However, the principal exemption for national security material is the (b)(1) exemption, which covers documents classified pursuant to the executive order. Since most litigation in this area will arise under the (b)(1) exemption, this Comment will focus on the latter provision in discussing the impact of the amendments on disclosure of national security information. 
The original statutory authority for withholding information was the Housekeeping Statute of $1789,{ }^{10}$ which gave executive departments the power to issue regulations pertaining to the custody, use, and preservation of their records and materials. The law proved an ideal vehicle for refusing to disclose government documents to private citizens. ${ }^{11}$

With the growth of governmental power and bureaucracy in the New Deal and World War II eras, conflicting drives emerged to open government up by enlarging public access to agency documents and to retain control over "national security" information through the classification system. Until 1966 no one attempted to resolve this conflict. National security interests, as determined by the agencies, almost automatically outweighed the interest in open government. With the passage of the FOIA the principles of access and classification were linked. The courts would have to find a balance between the competing considerations. Judicial construction of the Act, however, left the interests in place with national security supreme.

\section{Public Access}

Congress first formulated a general statutory plan to encourage access to agency records in 1946. Section 3 of the Administrative Procedure Act, passed that year, provided for disclosure and publication of agency procedures, opinions, and records. Disclosure of agency records was not required, however, "to the extent that there is involved ... any function of the United States requiring secrecy in the public interest."12 This exception left considerable room for agencies to maneuver around the Act, because the determination that the "public interest" demanded "secrecy" was left to the agency itself as a matter of discretion. The Act did not provide specifically for judicial review of an agency decision to withhold documents on "secrecy" grounds.

${ }^{10}$ Ch. $14, \S 7,1$ Stat. 68, as amended, REv. STAT. $\$ 161$ (1875), as amended, 5 U.S.C. $\S$ 301 (1970).

11 Security Classification, supra note 2, at 6. See also Reynolds v. United States, 192 F.2d 987, 992 (3d Cir. 1951), rev'd, 345 U.S. 1 (1953). In Reynolds, the Air Force relied on the Housekeeping Statute in its claim of executive privilege.

${ }^{12}$ Act of June 11, 1946, Pub. L. No. 79-404, § 3, 60 Stat. 238, as amended, 5 U.S.C. $\S 552$ (1970).

The stated congressional intent in enacting $\S 3$ was to open up agency files to the public. Subcomm. on Administrative Practice and Procedure, Senate Comm. on the Judiciary, Freedom of Information Act Source Book: Legislative Materials, Cases, Articles, S. Doc. No. 82, 93d Cong., 2d Sess. 6 (1974). 
In 1958 Congress tried to limit an agency's right to withhold information by amending the ancient Housekeeping Statute. The amendments provided that the statute could not be used to withhold information from the public or limit the availability of agency records. ${ }^{13}$ Again the amendments failed to provide for judicial review or enforcement.

Congress enacted the FOIA as a comprehensive attempt to set standards for public access to government information, to limit the areas in which disclosure could be denied, and to provide a remedy for wrongful withholding. The public's right of access to government files under the FOIA was not absolute, however. Subsection (b)(1) explicitly exempted material "specifically required by Executive order to be kept secret in the interest of the national defense or foreign policy."14 This exemption recognized the Executive's authority to classify certain information whose disclosure would threaten the national security.

\section{Classification}

The practice of classifying documents to prevent their release grew up during World War II. President Roosevelt issued an executive order directing that information revealing the nature and location of military installations and equipment be protected from disclosure. ${ }^{15}$ The purpose of the order, encompassing military secrets only, was to further the national military defense. But in the early 1950's, under the pressure of the Cold War and growing fears of the Communist threat, President Truman extended the classification system to all information, military and nonmilitary, whose secrecy was required for national security. The vague terms of the Truman order generated considerable controversy. ${ }^{16}$ In an effort to counter the criticism, President Eisenhower refined the classification system in Executive Order $10,501^{17}$ by reducing the number of agencies authorized to classify information and simplifying the classification system.

${ }^{13}$ Act of Aug. 12, 1958, Pub. L. No. 85-619, 72 Stat. 547, amending Rev. Stat. § 161 (1875) (codified at 5 U.S.C. $\$ 301(1970)$ ).

145 U.S.C. $\$ 552$ (b)(1), as amended, Pub. L. No. 93-502 (Nov. 21, 1974), 88 Stat. 1561 (1974 U.S. Code CONG. \& Ad. NEwS 5758).

${ }^{15}$ Exec. Order No. 8381, 3 C.F.R. 634 (Comp. 1938-1943).

${ }^{16}$ Exec. Order No. 10,290, 3 C.F.R. 789 (Comp. 1949-1953). For a general discussion of the history of the executive orders, see House Comm. ON Government Operations, Executive Classification-Problems Involving Exemption (b)(1) of The Freedom of Information Act (5 U.S.C. 552), H.R. Rep. No. 221, 93d Cong., 1st Sess. 8-14 (1973) [hereinafter cited as Executive Classification].

${ }^{17}$ Exec. Order No. 10,501, 3 C.F.R. 979 (Comp. 1949-1953). 
President Kennedy further modified Executive Order 10,501 to increase public access. ${ }^{18}$ The classification system remained substantially unchanged until March 1972 when President Nixon responded to controversy over documents classified pursuant to the orders by issuing Executive Order $11,652,{ }^{19}$ the order operative today. That order seeks to reduce the amount of classified material, provide means for earlier declassification, and aid implementation of these goals by the creation of a classification review committee. ${ }^{20}$

Until enactment of the FOIA, no authority existed under which classification decisions could be challenged administratively or judicially. The 1966 Act contained, for the first time, language that seemed to let private citizens seek judicial review of executive decisions to classify documents. ${ }^{21}$ Litigants responded to the apparent invitation by bringing suits testing the scope of agency discretion to classify documents, hoping that the courts would expand their review of classification decisions. The courts disappointed those expectations.

\section{B. Review Under the Original FOIA}

Epstein v. Resor ${ }^{22}$ was the first case to present the issue of the proper scope of judicial review of an agency's decision to withhold documents under the (b)(1) exemption to the FOIA. In Epstein, a history professor sought disclosure of documents dealing with the forced repatriation of anti-Communist Russians after World War II under a program known as "Operation Keelhaul." The documents were in a file classified "Top Secret," but the plaintiff argued that the classification was unwarranted and that the court should review the contents of the file to make its own determination about the propriety of the classification.

${ }^{18}$ Exec. Order No. 10,964, 3 C.F.R. 486 (Comp. 1959-1963). This executive order provided for an automatic declassification and downgrading system.

${ }^{19}$ Exec. Order No. 11,652, 3 C.F.R. 339 (1974).

${ }^{20}$ See generally Executive Classification, supra note 16, at 56-58. See also Note, Declassification of Sensitive Information: A Comment on Executive Order 11652, 41 Geo. Wash. L. REv. 1052 (1973).

${ }^{21} 5$ U.S.C. \& 552(a)(3) (1970), as amended, Pub. L. No. 93-502 (Nov. 21, 1974), 88 Stat. 1561 (1974 U.S. Code Cong. \& Ad. News 5758), provides:

On complaint, the district court of the United States . . . has jurisdiction to enjoin the agency from withholding agency records and to order the production of any agency records improperly withheld from the complainant. In such a case the court shall determine the matter de novo and the burden is on the agency to sustain its action.

${ }^{22} 296$ F. Supp. 214 (N.D. Cal. 1969), aff'd, 421 F.2d 930 (9th Cir.), cert. denied, 398 U.S. 965 (1970). 
The court declined to review the decision to classify the file:

To hold that the agencies have the burden of proving their action proper even in areas covered by the exemptions, would render the exemption provisions meaningless. If a determination de novo is made by this Court on whether the top secret classification by the Department of the Army is proper, with the burden on the Secretary to sustain its action, the court would be giving identical treatment to information withheld by an agency whether it fell within the exemption or not. ${ }^{23}$

With this reasoning, the court rendered meaningless the FOIA provision granting the courts jurisdiction to review agency decisions de novo. ${ }^{24} \mathrm{~A}$ brief incantation of any of the nine statutory exemptions ${ }^{25}$ would release the agency from accountability. The district court held that it would conduct only a limited review, to determine whether the agency classification was "clearly arbitrary and unsupportable." 26 The court then found, on the basis of affidavits rather than inspection of the documents themselves, that the classification was appropriate.

The Court of Appeals for the Ninth Circuit affirmed, even though it recognized that the decision of the lower court was too broad. The court of appeals restricted the decision to section (b)(1) on the theory that the exemption therein is "significantly different from the other exemptions." 27 The practical effect was to endorse the lower court's restrictive holding on the scope of review of national security classifications.

Nine months after Epstein and twenty-three years after the Army's creation of the "Operation Keelhaul" file, the Army downgraded the file's classification from "Top Secret" to "Confidential." The following year a White House aide stated that "[t]he United States Government has absolutely no objection . . . to the declassification and release of the 'Operation Keelhaul' files." 28 This rather ironic postcript to the Epstein decision suggests that the documents were classified improperly at the time suit was brought; and that the case might have come out differ-

${ }^{23} 296$ F. Supp. at 217.

${ }^{24} 5$ U.S.C. $\$ 552(a)(3)(1970)$.

${ }^{25}$ See note 6 supra.

26296 F. Supp. at 217.

27421 F.2d at 933.

${ }^{28}$ Letter from Associate Counsel to the President to Plaintiff, October 22, 1970, cited in Wolfe v. Froehlke, 358 F. Supp. 1318, 1319 n.1 (D.D.C. 1973), aff'd, 510 F.2d 654 (D.C. Cir. 1974). 
ently had the court examined them in camera or at least required the Army to justify the classification. ${ }^{29}$

Nevertheless the courts continued to decline review of documents withheld under the national security exemption. Besides lowering the standard of review, the courts limited the scope of review by evincing reluctance to examine the contents of contested documents. In Moss $v$. Laird, ${ }^{30}$ Congressman John Moss sought the release of the forty-seven-volume History of U.S. Decision-Making Process on Vietnam Policy (the Pentagon Papers) after the Defense Department refused to disclose the documents. In upholding the Pentagon's decision, Judge Gesell noted that the Pentagon had reviewed the volumes fully earlier that year and declassified large portions already published in newspapers and in book form. Sworn affidavits were submitted to the court which suggested that disclosure of portions still classified would compromise American defense arrangements, military plans, diplomatic negotiations, and intelligence strategies. ${ }^{31}$ Citing Epstein $v$. Resor, the court found in camera inspection unnecessary and inappropriate. ${ }^{32}$

The issue of the propriety of in camera perusal of documents withheld by reliance on the (b)(1) exemption was settled by the Supreme Court in EPA v. Mink. ${ }^{33}$ Justice White stated for the Court that Congress specifically precluded judicial inspection of the contents of classified documents:

We do not believe that Exemption 1 permits compelled disclosure of documents . . . that were classified pursuant to this Executive Order. Nor does the Exemption permit in camera inspection of such documents to sift out so-called "nonsecret components." Obviously, this test was not the only alternative available. But Congress chose to follow the Executive's determination in these matters and that choice must be honored..$^{34}$

${ }^{29} \mathrm{~A}$ second attempt was made to procure disclosure of the "Operation Keelhaul" files in Wolfe v. Froehlke, 358 F. Supp. 1318 (D.D.C. 1973), aff'd, 510 F.2d 654 (D.C. Cir. 1974). The Army again refused disclosure, this time on foreign policy grounds because the British, with whom the file had been jointly created, did not agree to declassification. The Army's decision was upheld. See text accompanying notes $105 \& 106$ infra.

${ }^{30}$ Civil No. $1254-71$ (D.D.C., Dec. 7, 1971).

${ }^{31} I d$. at 2.

${ }^{32}$ Id. at 3 .

${ }^{33} 410$ U.S. 73 (1973).

${ }^{34} I d$. at 81. 
Relying in part on the language of the (b)(1) exemption, which provided that matters "specifically required by Executive Order" to remain secret need not be disclosed, the Court reasoned that once a document was classified no further inquiry into its contents could be made. The "de novo" review requirement applied only to the other eight enumerated exemptions.

Although the Court's holding was not entirely clear, its analysis suggested that even the limited review for arbitrariness of Epstein may have been impermissible. Judicial limitations on judicial review, first by Epstein's restriction of the scope of the inquiry and then in Mink by curtailment of the means of review available to the courts, produced predictable results. The resulting case law contained challenges to the efficacy of the FOIA, the credibility of the Excutive, and the reliability of the judiciary.

\section{Results Under the Original FOIA}

As construed by the courts, the original FOrA failed to guarantee ready public access to information pertinent to critical public issues. In Mink itself, Congresswoman Patsy Mink sought release of documents that supposedly justified the decision to conduct a nuclear test known as "Cannikin" on Amchitka Island, Alaska. Her request was denied. As a result, the growing debate over the widsom of conducting the test was silenced. After the explosion, almost all the materials sought by the plaintiffs in Mink were released to the public. The disclosure of the documents severely undercuts the Executive's position that the documents had to be withheld for national security reasons. The more plausible explanation is that the Executive wanted to avoid controversy by suppressing any information that would have strengthened the case of the opposition. ${ }^{35}$

Misuse of the national security exemption also occurred in Aspin v. Department of Defense ${ }^{36}$ in which Congressman Les Aspin sought release of the Peers Commission Report on the My Lai incident in Vietnam. The Army refused to release the report, citing as authority four different exemptions in the FOIA. ${ }^{37}$ The (b)(1) national security exemption was not among them. The

${ }^{35}$ House Hearings, supra note 8 , at 87.

${ }^{36} 491$ F.2d 24 (D.C. Cir. 1973).

${ }^{37}$ Letter from Robert W. Berry, General Counsel, to Congressman Aspin, March 1, 1972, on file in the United States District Court for the District of Columbia. The four exemptions cited as a basis for withholding the reports were: (1) confidential information-(b)(4); (2) intra-agency memorandum-(b)(5); (3) personal privacy-(b)(6); and (4) investigatory file- $(b)(7)$. 
Army raised the (b)(1) objection only after Congressman Aspin filed suit, and then in conjunction with an argument that in camera review was inappropriate. ${ }^{38}$ Shortly after Lieutenant William Calley, Jr., the platoon leader at My Lai and the sole participant convicted of any My Lai wrongdoing, was released from jail, the Army released the Peers Commission Report. ${ }^{39}$ The release of the document as soon as the investigatory file exemption no longer applied, without further declassification, suggests that the Army only invoked the (b)(1) exemption to avoid in camera review under Mink. ${ }^{40}$

By the spring of 1973 Congress had become aware of the problems of the FOIA as it then existed. The Nixon Administration was subjecting the national security label to abuse, the courts hesitated to expand their own scope of review, and the Supreme Court had hinted in Mink that an appropriate solution would have to come from the legislative branch. ${ }^{41}$ Congress accepted the challenge and proceeded to search for a remedy.

\section{The New Legislation}

The FOIA amendments enacted in November 1974 authorize the courts to inspect in camera documents classified pursuant to an executive order. They also provide for de novo review of agency decisions to withhold requested material. ${ }^{42}$ The

${ }^{38}$ See Memorandum of Points and Authorities in Support of Plaintiff's Motion for Summary Judgment at 6, Aspin v. Dep't of Defense, 491 F.2d 24 (D.C. Cir. 1973); Memorandum of Points and Authorities in Support of Defendant's Motion to Dismiss or in the Alternative for Summary Judgment at 14-15. Id. The trial court's opinion did not mention the issue at all, and the court of appeals found it unnecessary to rule on the question. Aspin v. Dep't of Defense, 348 F. Supp. 1081 (D.D.C. 1972), aff'd, 491 F.2d 24 (D.C. Cir. 1973).

${ }^{39}$ N.Y. Times, Nov. 14,1974 , at 16 , col. 4.

40 A third case demonstrating the need for judicial review of classification decisions is Consumers Union v. Peterson, Civil No. 131-73 (D.D.C., Jan. 22, 1973). Consumers Union requested disclosure of a Department of Commerce document concerned with the formulation of textile import policy and administration. The Department of Commerce contended that disclosure was not required because of the (b)(1) exemption. At that time the document was classified "confidential." The Department of Commerce later agreed in a settlement to declassify and release the document. Letter from Eldon V.C. Greenberg to Congressman Moorhead, May 24, 1973, in House Hearings, supra note 8, at 361-63. The guidelines set forth in the document are of a most general nature, whose disclosure could not conceivably have compromised the nation's security or foreign policy. See Recommended General Policy Guidelines for Third Year of the Long Term Agreement, in House Hearings, supra note 8, at 363-64. If the Commerce Department had not agreed to settle the case, the courts would not have compelled disclosure under the FOIA as it then existed and was interpreted.

"See text accompanying note 34 supra.

42 Pub. L. No. 93-502 (Nov. 21, 1974), 88 Stat. 1561 (1974 U.S. Code Cong. \& AD. NEws 5758), amending 5 U.S.C. $\$ 552$ (1970). 
legislative history of the amendments reveals Congress' unmistakable intent to encourage the courts to become actively involved in security classification decisions.

Both the Senate and the House held extensive hearings on the proposals to overule Mink by amending the FOIA. The bill reported out of the Senate Judiciary Committee a year after Mink made two substantial changes in the existing national security exemption. ${ }^{43}$ First, the Senate bill explicitly required that material could be withheld under the (b)(1) exemption only if a court determined that the documents bore a national security stamp and that the stamp was correctly applied. ${ }^{44}$ The mere fact of classification would not terminate the court's inquiry. The court would also be obliged to consider the justification offered by the agency for its decision to classify the documents.

By requiring that documents be properly classified "in fact", the Senate bill dramatically increased the role of the courts in enforcement of the FOIA. The authority to classify documents would no longer rest exclusively in the agency's discretion, but would be shared with the courts. But the question of the degree of judicial participation remained unanswered.

The bill's second major change, the subject of considerable debate, related to this issue of degree. The Senate bill as reported out of committee established new procedures and standards which the courts were to follow in exercising their new authority to review agency classification decisions. The bill authorized in camera review of contested documents when courts were unable to resolve the matter on the basis of affidavits submitted by the parties. If, however, the head of an agency filed an affidavit certifying that he had examined the documents and determined that disclosure was improper, the court would be obligated to uphold the agency decision unless in camera inspection revealed no reasonable basis for the decision. ${ }^{45}$

${ }^{43}$ S. 2543, 93d Cong., 2d Sess. § 2(a) (1974), was reported out on May 16, 1974, S. Rep. No. 855, 93d Cong., 2d Sess. (1974).

${ }^{44}$ S. 2543, 93d Cong., 2d Sess. (1974), provided: "Section 552(b)(1) of title 5, United States Code, is amended to read as follows: '(1) specifically required by an Executive order or statute to be kept secret in the interest of national defense or foreign policy and are in fact covered by such order or statute . ..." (emphasis supplied).

${ }^{45}$ S. 2543, 93d Cong., 2d Sess. § I(b)(2) (1974) provided:

If there has been filed in the record an affidavit by the head of the agency certifying that he has personally examined the documents withheld and has determined after such examination that they should be withheld under the criteria established by a statute or Executive order referred to in subsection (b)(1) of this section, the court shall sustain such withholding unless, following its in camera examination it finds the withholding is without a reasonable basis under such criteria. 
The courts, in sum, would be authorized to inspect documents withheld pursuant to the national security exemption, but review would be limited to a "reasonableness" standard. Senator Hruska explained that the "reasonable basis" test would prevent a judge from substituting his understanding of a document's sensitive nature for that of the agency ${ }^{46}$ The Senate bill, then, would not have substantially altered the role played by courts under the then-existing statutory and case law. In both Epstein v. Resor $^{47}$ and Moss $v$. Laird ${ }^{48}$ the court recognized that the decision to classify was reviewable for arbitrariness. Whether this minimal review survived the Supreme Court's decision in $M i n k^{49}$ is open to some question. If it did, the bill would only have expanded the scope of review a little further; if it did not, the bill would have revived and broadened the pre-Mink rule. In either case, the courts would still have been unable to redetermine de novo the proper security classification of contested documents.

On the Senate floor, Senator Muskie proposed an amendment that broadened substantially the scope of judicial review. The Muskie amendment prevailed, and Congress enacted it over a presidential veto which was motivated in part by opposition to the amendment. ${ }^{50}$ The amendment eliminated the section on procedures and the "reasonable basis" standard. 51 The judiciary, Muskie had argued, is fully capable of making intelligent decisions in the area of national defense without being restricted by Congress:

By telling judges so specifically how to manage their inquiry into the propriety of a classification marking, we show a strange contempt for their ability to devise procedures on their own to help them reach a just decision. Moreover, by giving classified material a status unlike that of any other claimed Government secret, we foster the outworn myth that only those in possession of military and diplomatic confidences can have the expertise

46120 Cong. Rec. S9326 (daily ed. May 30, 1974) (remarks of Senator Hruska).

47421 F.2d 930 (9th Cir.), cert. denied, 398 U.S. 965 (1970).

${ }^{48}$ Civil No. 1254-71 (D.D.C., Dec. 7, 1971).

${ }^{49}$ EPA v. Mink, 410 U.S. 73 (1973).

so 10 Weekly Compilation of Presidential Documents 1318 (1974) ("Veto of Freedom of Information Act Amendments," Oct. 17, 1974) [hereinafter cited as VEro MEsSaGe].

${ }^{51}$ Senator Ervin summed up congressional sentiment: "The ground ought to be not whether a man has reached a wrong decision reasonably or unreasonably. It ought to be whether he has reached a wrong decision." 120 ConG. REc. S9326 (daily ed. May 30, 1974) (remarks of Senator Ervin). 
to decide with whom and when to share their knowledge. ${ }^{52}$

The final version of the legislation embodies the position advocated by Senator Muskie. The law now explicitly requires de novo review for all materials withheld on national security grounds, and permits in camera inspection at the court's discretion. ${ }^{53}$ It also expands the courts' scope of review by changing the language of the (b)(1) national security exemption to cover material "specifically authorized under criteria established by an Executive order to be kept secret in the interest of national defense or foreign policy and ... in fact properly classified pursuant to such Executive order." 54 This new language directs the court to use the criteria set forth by the Executive as a standard for judging the propriety of the agency's determination. The Conference Report ${ }^{55}$ makes clear that the court must consider both procedural and substantive criteria contained in the executive order or statute, though still attributing substantial weight to the agency's affidavit concerning details of the classification decision.

Congress' intent in passing the new legislation, then, was to encourage the courts to play a more substantial role in FOIA cases. The national defense or foreign policy exemption should be treated like all other exemptions. The legislation does not direct courts to disregard agency decisions or an agency's reasons for its decision; it only removes the presumption in the agency's favor. Based on all the information presented, a court must reach its own independent judgment, a far cry from the situation before 1974 when courts were denied information and asked to abstain from reaching any kind of judgment at all. ${ }^{\mathbf{5 6}}$

${ }^{52}$ Id. $\mathbf{S 9 3 1 9}$ (remarks of Senator Muskie).

53 The law provides that the district court has jurisdiction to enjoin an agency from withholding records:

In such a case the court shall determine the matter de novo, and may examine the contents of such agency records in camera to determine whether such records or any part thereof shall be withheld under any of the exemptions set forth in subsection (b) of this section, and the burden is on the agency to sustain its action.

Pub. L. No. 93-502 § (b)(2) (Nov. 21, 1974), 88 Stat. 1561 (1974 U.S. Code Cong. \& Ad. News 5758), amending 5 U.S.C. $\$ 552$ (1970).

54 Pub. L. No. 93-502, § 2(a) (Nov. 21, 1974), 88 Stat. 1561 (1974 U.S. Code ConG. \& AD. NEws 5758), amending 5 U.S.C. $\$ 552$ (1970) (emphasis supplied).

${ }^{55}$ H.R. ReP. No. 1380, 93d Cong., 2d Sess. 12 (1974).

56 Evidence of Congressional intent to encourage judicial scrutiny of the Government's national security claims can also be found in the legislative history of the Federal Rules of Evidence, Pub. L. No. 93-595 (Jan. 2, 1975), 88 Stat. 1926 (1974 U.S. Code Cong. \& Ad. News 1) (special pamphlet no. 12A), enacted two months after the 


\section{The Judicial Response to the FOIA Amendments: Heritage of Hesitation}

The 1974 FOIA amendments, as yet untouched by judicial construction, invite the courts to delve into the national security classification system. The invitation, however, is not a command. By refusing to employ the discretionary powers granted, by reading the statute narrowly, or by raising questions of justiciability, the courts could decline to accept the role envisioned for them by the legislature.

Will the courts be willing to confront the executive branch on the uncertain territory of foreign affairs and national defense? Only months after enactment of the amendments, it is too early to answer the question definitively. But it is possible to define the possibilities by looking at other areas of the law in which executive agencies have submitted national security claims to courts to justify agency action. In four areas, cases have raised the kinds of issues that can be expected to arise under the FOIA amendments. In cases involving the judicial review provisions of the Administrative Procedure Act, claims of executive privilege, wiretap and surveillance authorizations, and the FOIA before its amendment, courts have been reluctant to overrule agency decisions. This reluctance may portend unwillingness to accept the latest mandate from Congress.

\section{A. The Administrative Procedure Act}

The Administrative Procedure $\mathrm{Act}^{57}$ (APA) provides for judicial review of decisions made by administrative agencies. Although the Act does not specifically prohibit review of any particular subject, it has been interpreted to preclude review of foreign affairs decisions. Professor Davis argues that section $701(\mathrm{a})(2)$ of the Act, precluding judicial review of agency action

FOIA amendments. The rules as drafted by the Advisory Committee included a state secret privilege (rule 509), which was substantially the same as the FOIA (b)(1) exemption. Before the rules were sent to Congress, the Court amended the state secret privilege, on the urging of the Justice Department, to expand the definition of state secret and limit the courts' role in evaluating the Government's claim. Hearings on Proposed Rules of Evidence Before the Special Subcomm. on Reform of Federal Criminal Laws of the House Comm. on the Judiciary, 93d Cong., 1st Sess. 181-85 (1973).

The proposed rule met with considerable opposition in Congress. The rule would have conflicted with the basic purpose of the FOIA amendments, even though its use would arise in a different context from the FOIA. The latter were designed to expand rather than contract the courts' authority to review national security claims. The rule was eliminated from the version ultimately enacted.

For a general discussion of the rule and its legislative history, see id. 181-85 (1973).

575 U.S.C. $\$ \S 551-59$ (1970). 
to the extent that the latter "is committed to agency discretion by law,"58 excludes certain subjects from judicial consideration; and foreign policy questions usually fall into this excluded category. ${ }^{\mathbf{5 9}}$

On the other hand, section 706(2)(A) of the APA provides that the scope of judicial review of agency action shall include a determination whether the agency has abused its discretion. ${ }^{60} \mathrm{By}$ reading the two provisions together, Professor Raoul Berger concludes that all decisions are reviewable, except that decisions committed to agency discretion are reviewable only for abuse of discretion. ${ }^{61}$

The debate between Davis and Berger is partly a linguistic controversy over the intent of the APA, a debate not relevant to the FOIA. But it is also a dispute over the propriety of judicial review in the foreign affairs context. The substance of the debate is reflected in the decision of the United States Court of Appeals for the District of Columbia Circuit in Curran v. Laird, ${ }^{62}$ with the majority of the court adopting the Davis approach and the minority following Berger.

In Curran, the maritime union brought an action under the Cargo Preference Act, ${ }^{63}$ challenging an executive decision to use foreign vessels to transport American military cargo. The Act prohibited such use unless equivalent American ships were unavailable. The maritime union argued that ships in the national defense reserve fleet were available, and that the Act required their use before resort to foreign ships. The Department of Defense claimed the ultimate authority to decide, in the interest of national defense, whether the reserve fleet should be used to transport cargo. In short, the Department claimed that the question of "availability" had been committed exclusively to its discretion by law. The court agreed with the Pentagon and refused to review the decision. ${ }^{64}$

In dissent, Judge Skelly Wright argued that the Executive must consider the policy behind the Cargo Preference Act-the protection of American seamen-in determining whether the re-

${ }^{58} 5$ U.S.C. $\$ 701(\mathrm{a})(2)(1970)$.

59 Davis, Administrative Arbitrariness $\rightarrow$ A Final Word, 114 U. PA. L. REv. 814 (1966). Professor Davis' position is that it would be impractical to let courts review all administrative action. He cites a series of examples to bolster his argument, many of which raise foreign affairs problems. Id. 821-33.

${ }_{60} 5$ U.S.C. $\$ 706(2)(A)$ (1970).

${ }^{61}$ Berger, Administrative Arbitrariness and Judicial Review, 65 Colum. L. Rev. 55 (1965).

${ }^{62} 420$ F.2d 122 (D.C. Cir. 1969).

6310 U.S.C. \& 2631 (1970).

64420 F.2d at 131. 
serve fleet was "available" for use. Following Professor Berger's analysis, he argued that the Executive's decision should be reviewed for abuse of discretion. To avoid the need for case-bycase analysis, the dissent suggested that the Executive publish a broad policy statement covering all cases that might arise. ${ }^{65}$

The relevance of Curran to the FOIA lies not in its interpretation of the conflicting APA provisions on judicial review, but rather in its analysis of the court's role in national defense. The majority and the dissent agreed that the court's function is limited when national security issues are involved. But while the dissent would permit circumscribed review, the majority found review inappropriate: "[T]he particular issues," said the court, "call for determinations that lie outside sound judicial domain in terms of aptitudes, facilities, and responsibility."66

The Davis approach, as adopted by the Curran court, not only limits the scope of judicial review but denies the very availability of judicial review. The court based its decision on its perception of the proper judicial function in the foreign affairs area. The court's rationale applies only indirectly to the declassification context, but it suggests that in national security cases, the courts are likely to adhere to the traditional model of judicial deference to the Executive, instead of exercising the new discretion that is theirs under the FOIA amendments.

\section{B. Invocation of Executive Privilege}

During the course of ordinary litigation, private parties may need access to government documents to prove their cases. If the material sought contains sensitive information which the Government does not wish to disclose, then the Executive will interpose a claim of privilege. Resolving the conflict between the litigant's interest in obtaining pertinent and even necessary information and the Government's interest in preserving sensitive material is a task for which the courts are well suited.

The "state secrets" privilege has long been recognized by the judiciary. ${ }^{67}$ When the courts are confronted with the claim, they usually respect the Executive's decision without in camera inspection of the contested material. ${ }^{68}$ This is another indication that

${ }^{63} I d$. at 142 (Wright, J., dissenting).

${ }^{66} I d$. at 129. See also text accompanying notes 107-56 infra.

${ }^{67}$ See, e.g., Totten v. United States, 92 U.S. 105 (1875); Carl Zeiss Stiftung v. V.E.B. Carl Zeiss, Jena, 40 F.R.D. 318 (D.D.C. 1966), aff d sub nom. V.E.B. Carl Zeiss, Jena v. Clark, 384 F.2d 979 (D.C. Cir.), cert. denied, 389 U.S. 952 (1967).

${ }^{68}$ See, e.g., United States v. Haugen, 58 F. Supp. 436 (E.D. Wash. 1944); Pollen v. Ford Instrument Co., 26 F. Supp. 583 (E.D.N.Y. 1939); Firth Sterling Co. v. Bethlehem 
courts might be reluctant to exercise their expanded power over declassification cases under the amended FOIA.

In United States $v$. Reynolds, ${ }^{69}$ the plaintiffs, widows of civilian observers who were killed in an Air Force test flight, moved for production of the Air Force's official accident investigation report. The Government moved to quash on the ground that the material could not be supplied without seriously damaging the national security. It asserted the evidentiary privilege of military secrets, as codified in an Air Force regulation. The court recognized its obligation to determine the appropriate scope of the claimed privilege. It sustained the withholding of the records, however, on the basis of only a formal claim of privilege, a supporting affidavit, and judicial notice of the contemporaneous "vigorous preparation for national defense."70

The Court declined to order inspection of the documents in camera, but noted that the relative necessity of obtaining the evidence would determine the depth of its probe of a claim of privilege. ${ }^{71}$ The Government had offered to produce three surviving crewmen for examination on non-classified matters, and the Court found that their testimony would obviate the need for immediate production of the report. The Reynolds Court may have reached the correct result, but it should have looked at the documents to be sure. The case also suggests that courts may seize upon the existence of other evidence when they want to defer to the Executive by not ordering production of documents even for in camera inspection.

In another case involving mixed claims of executive privilege and national security, the District of Columbia Circuit also declared that the lower court should investigate claims of privilege, but avoided requiring in camera inspection of the "national security" documents involved. In Committee for Nuclear Responsibility, Inc. v. Seaborg, ${ }^{72}$ plaintiffs challenged the adequacy of an environmental impact statement prepared by the Atomic Energy Commission pursuant to the National Environmental

Steel Co., 199 F. 353 (E.D. Pa. 1912). But see Halpern v. United States, 258 F.2d 36 (2d Cir. 1958); Cresmer v. United States, 9 F.R.D. 203 (E.D.N.Y. 1949) (contested documents required to be submitted to the court for in camera inspection). In Cresmer the court inspected the documents, found no state secrets in them, and ordered the government to disclose the material.

${ }^{69} 345$ U.S. 1 (1953).

70 Id. at 10 .

${ }^{71} I d$. at 11 .

72463 F.2d 788 (D.C. Cir. 1971). The plaintiffs in Committee for Nuclear Responsibility challenged the nuclear test that was also the subject of dispute in EPA v. Mink, 410 U.S. 73 (1973). 
Policy Act $^{73}$ (NEPA). They sought discovery of certain agency memoranda which criticized the decision to conduct a nuclear test because of its potentially adverse environmental impact. The Government refused to disclose the memoranda on executive privilege grounds. The basis of the claim of privilege was that the materials requested contained intra-executive advisory opinions and recommendations whose confidentiality was necessary to protect the integrity of the executive decisonmaking process.

The court rejected the Government's argument that the Executive's determination that documents are protected by privilege is conclusive, holding that the applicability of the privilege must be determined by the district court. The court concluded that in camera inspection of the contested documents was proper in making that determination. ${ }^{74}$

Just as the court in Reynolds declined to inspect documents that concerned national security matters, so in Committee for Nuclear Responsibility the court declined to inspect portions of documents that concerned national security matters. The court affirmed an order requiring the Government to submit the contested documents for in camera inspection after excising material containing military or diplomatic secrets. ${ }^{75}$ The court did not require that these allegedly sensitive portions of the documents be turned over to the court, leaving to the Executive the crucial decision of what constituted national security information without any judicial review. In camera inspection was ordered only of the nonsensitive environmental documents.

The question of the courts' proper role in deciding the scope of executive privilege arose recently in connection with the Watergate Special Prosecutor's efforts to obtain taped White House conversations relevant to investigation of the Watergate scandal. The District of Columbia Circuit held that in camera inspection of the tapes was necessary. ${ }^{76}$ The court went so far as to authorize review of a claim of privilege based on national security:

In so far as the President makes a claim that certain material may not be disclosed because the subject matter relates to national defense or foreign relations, he may decline to transmit that portion of the material and

${ }^{73} 42$ U.S.C. $\S 4332$ (C) (1970).

74463 F.2d at 792-95.

${ }^{75} \mathrm{Id}$. at 790-91.

${ }^{76}$ Nixon v. Sirica, 487 F.2d 700 (D.C. Cir. 1973). 
ask the District Court to reconsider whether in camera inspection of the material is necessary. ${ }^{77}$

Although the court recognized the validity of in camera review, it contemplated that the lower court would order in camera inspection less readily when the Executive based his claim on national security than when he based it on the need to preserve the confidentiality of the executive decisionmaking process. If the court found the claim of privilege unsupported, it could order production of the documents for in camera inspection. The court left the standard for determining the validity of the claim undefined, however.

The Supreme Court has intimated that mere claims of national security will preclude in camera inspection. In United States $v$. Nixon, ${ }^{78}$ the Court left open this possibility while affirming a court's power to review executive privilege claims resting on the need for confidential communications:

Absent a claim of need to protect military, diplomatic, or sensitive national security secrets, we find it difficult to accept the argument that even the very important interest in confidentiality of Presidential communications is significantly diminished by production of such material for in camera inspection . . . .79

As Professor Van Alstyne has suggested, the Court offered an "oblique invitation to the President to throttle judicial review by presenting a claim of executive privilege in the cellophane wrapper of 'national security." "80

The lesson that can be drawn from these cases is that even when the courts are faced with claims of state secret privilege that they are not prohibited from reviewing, they are reluctant to undertake in camera inspection. Although the courts have consistently held that it is their job to determine the appropriate scope of the privilege, they tend to defer to the Executive's determination when the claim of privilege rests on national security grounds.

The courts may adopt a similarly cautious approach in cases under the FOIA amendments. Without considerable provocation, courts will not be likely to shed their excessive respect for

${ }^{77} \mathrm{Id}$. at 721 .

78418 U.S. 683 (1974).

${ }^{79} \mathrm{Id}$. at 706 (emphasis supplied).

so Van Alstyne, $A$ Political and Constitutional Review of United States v. Nixon, 22 U.C.L.A. L. REv. 116, 117 (1974). 
the executive privilege doctrine. Given that respect, it is unlikely that courts will demand in camera inspection of classified documents except in the most clear-cut cases of misuse of the privilege. Even when the courts order in camera inspection of classified documents, they will probably seldom overturn the decision of the agency.

\section{Wiretap Cases}

The courts' approach in electronic surveillance cases may also illuminate current judicial attitudes toward inspection of documents bearing on national security matters. In most cases, the fourth amendment requires that the government seek prior judicial approval in the form of a warrant before conducting a search. ${ }^{81}$ The courts have carved out exceptions to the warrant requirement: in certain limited circumstances a warrantless search does not violate the fourth amendment. ${ }^{82}$ On several occasions the Government has claimed that electronic surveillance conducted for national security purposes qualifies as an exception to the warrant requirement, with mixed results in the courts.

The Government did not prevail in United States $v$. United States District Court. ${ }^{83}$ There the Government argued that a warrantless wiretap of the defendants was proper because the purpose of the surveillance was to gather intelligence information needed to protect the national security. The Government relied on the language of Title III of the Omnibus Crime Control and Safe Streets Act, ${ }^{84}$ which authorizes court-approved electronic surveillance for specific crimes but also provides that nothing in the Act is intended to limit the President's constitutional powers to protect against the overthrow of the government. ${ }^{85}$ The Government argued that requiring a warrant would inhibit the President's ability to protect the nation from internal subversion, that the judiciary lacked expertise in national security matters, that Congress recognized this problem by providing in the Act for warrantless searches in some cases, and that therefore national security wiretaps should be excepted from the warrant requirement.

${ }^{81}$ See, e.g., Johnson v. United States, 333 U.S. 10 (1948).

${ }^{82}$ See, e.g., Chimel v. California, 395 U.S. 752 (1969) (search incident to arrest); United States v. Harris, 390 U.S. 234 (1968) (plain view); Warden v. Hayden, 387 U.S. 294 (1967) (hot pursuit).

83407 U.S. 297 (1972).

8418 U.S.C. §§ 2510-20 (1970).

${ }^{85} 18$ U.S.C. § 2511(3) (1970). 
In an opinion written by Justice Powell, the Court rejected the Government's statutory argument. Congress, the Court concluded, had taken a neutral position on the question of the need for a warrant in national security cases. ${ }^{86}$ Although the President is obligated to protect the national security, his constitutional function would not be hampered by requiring prior judicial approval of domestic security surveillance. In balancing the Executive's need to prevent internal subversion against the need to protect privacy and free expression, the Court concluded that the Government must obtain a warrant before conducting any domestic electronic surveillance. The fourth amendment guarantee against unreasonable searches could not be ensured if domestic security wiretaps could be conducted solely at the discretion of the Executive. ${ }^{87}$

Eschewing the exclusivity of executive expertise, the Court declared that federal courts are fully competent to deal with cases involving national security:

There is no reason to believe that federal judges will be insensitive to or uncomprehending of the issues involved in domestic security cases. Certainly courts can recognize that domestic security surveillance involves different considerations from the surveillance of "ordinary crime." If the threat is too subtle or complex for our senior law enforcement officers to convey its significance to a court, one may question whether there is probable cause for surveillance. ${ }^{88}$

Thus the Court refused to create a blanket exception to the warrant requirement for all national security cases. The decision in United States v. United States District Court demonstrates that the Supreme Court is prepared to see the federal courts play an active role in scrutinizing government claims of national security when the claims are invoked at the expense of personal freedoms.

By analogy, the courts should be prepared to exercise their new powers of review under the FOIA amendments. The courts may attempt to distinguish District Court because it involved a balancing of fundamental constitutional rights, whereas claims under the FOIA are only statutory claims to be sacrificed in the interest of national security. The statutory basis of the right of

\footnotetext{
86407 U.S. at 306-08.

${ }^{87} \mathrm{Id}$. at $316-17$.

${ }^{88}$ Id. at 320 .
} 
access, however, should not detract from that right's importance as a contribution to the constitutional scheme of self-government.

Essential to such a scheme is continual access to social, political, esthetic, and moral experiences and ideas. ${ }^{89}$ To deprive the public of the factual basis of such ideas is to curtail robust and free debate, the goal of the first amendment protection of speech. The rights secured by the FOIA, while not absolutely mandated by the Constitution, further the purposes of the Bill of Rights and should not be easily overborn, even by the Government's invocation of national security.

Even if one accepts that the statutory/constitutional distinction does not destroy the analogy, District Court may be irrelevant to cases involving foreign affairs under the FOIA. In District Court, the Supreme Court deliberately limited itself to the question of domestic surveillance. The Court carefully reserved the question of the scope of the Executive's power to monitor the activities of foreign governments, both within and outside the country. ${ }^{90}$ The Court of Appeals for the Third Circuit confronted the issue in United States $v$. Butenko $^{91}$ in which the defendants were charged with conspiring to transmit national defense information to a foreign government. The Government justified having conducted electronic surveillance without a warrant under District Court because foreign intelligence rather than domestic security was at issue.

A majority of the court agreed with the Government, holding that surveillance conducted for the purpose of gathering foreign intelligence information constitutes an exception to the fourth amendment's warrant requirement. ${ }^{92}$ The court found that judicial intervention in the surveillance process would frustrate the Executive's conduct of foreign affairs by threatening to interfere with the continuous flow of intelligence information. ${ }^{93}$ The fourth amendment only requires judicial review of the reasonableness of the wiretap subesequent to the surveillance, and then only in certain situations, such as the trial of the subject

89 See Red Lion Broadcasting Co. v. FCC, 395 U.S. 367, 390 (1969).

${ }^{90} 407$ U.S. at 308. But see Russo v. Bryne, 409 U.S. 1219 (Douglas, Circuit Justice, 1972), where Justice Douglas refused to distinguish between foreign and domestic surveillance, claiming that prior decisions drew no such lines. The issue remained unresolved.

91494 F.2d 593 (3d Cir.), cert. denied, 95 S. Ct. 147 (1974).

92494 F.2d at 605 . The purpose of the wiretap in Butenko had been to prevent the illegal dissemination of sensitive information, not to gather foreign intelligence information, but the court saw no reason to treat the two situations differently. Id. at n.51.

${ }^{93} \mathrm{Id}$. at 602-03. 
of surveillance on the basis of information obtained by the contested wiretap. The amendment does not require prior approval of surveillance by the courts.

The court's holding was considerably broader than was necessary. As Judge Gibbons pointed out in dissent, ${ }^{94}$ the court could have examined the precise circumstances of the case to determine whether an emergency made it impossible for the Government to secure a warrant. Instead, the court created a broad exception for all foreign intelligence cases, whether or not the government could have obtained a warrant before commencing surveillance. As in the executive privilege cases, ${ }^{95}$ the court evinced an inclination to defer to the Executive.

District Court and Butenko, taken together, indicate that courts are more wary of scrutinizing national security claims when foreign affairs issues are implicated than when domestic security alone is at stake. This self-imposed limitation on judicial review in the surveillance area may be adopted by the courts in cases arising under the FOIA. The degree to which foreign affairs issues complicate the request for disclosure is likely to be a factor that courts weigh in the balance when they consider whether in camera review is appropriate.

\section{FOIA Cases Prior to Amendment of the Act}

A central feature of the 1974 FOIA amendments is that the authorization for in camera inspection of contested documents is permissive rather than mandatory. ${ }^{96}$ Addressing the merits of the classification system to determine whether a classification is "in fact" proper requires, in critical cases, analysis of the actual content of the contested documents. Refusal to gaze upon the forbidden papers may be judicial abdication of ultimate responsibility. The courts' willingness to exercise their discretionary powers may determine the effectiveness of the amendments.

An examination of the FOIA cases decided before the amendments became effective reveals an attitude of judicial caution that goes beyond the bare language of the Act. In cases involving documents bearing a national security stamp, the courts not only narrowed the scope of review to whether the

${ }^{94} \mathrm{Id}$. at 637 (Gibbons, J., dissenting).

${ }^{95}$ See text accompanying notes 67-80 supra.

96 The original bill considered by the Senate, S. 1142, and the original bill considered by the House, H.R. 5425, provided for mandatory in camera review by federal courts whenever the Government made a claim under the $(b)(1)$ exemption. The bills that eventually were debated by the two Houses on the floor, S. 2543 and H.R. 12471, gave the courts the power to examine documents in camera. 
administrative decision was arbitrary and capricious; ${ }^{97}$ they also confined themselves to minimal in camera inspection of contested classified documents. In Soucie v. David, ${ }^{98}$ for instance, the Court of Appeals for the District of Columbia Circuit instructed the district court to avoid handling the actual documents themselves. The court of appeals noted that in camera perusal of documents might be necessary, but only if the Government's description of the documents did not satisfy the court of the claim's justification. ${ }^{99}$ Even absent a statutory constraint, the court was willing to curtail judicial rumaging through classified documents.

Similarly, in Moss v. Laird ${ }^{\mathbf{1 0 0}}$ the court indicated that in camera perusal of contested documents, even if not prohibited by the Act, would not be "desirable." In camera inspection, said the court, would require that a substantial portion of the litigation take place in secret, with the judge forced to rely on extensive ex parte briefings on matters beyond the court's competence. The party seeking disclosure would effectively be excluded from the process. Such a departure from normal courtroom procedure, the court concluded, could be allowed only in the most compelling circumstances. ${ }^{101}$

Congress apparently shared Judge Gesell's concern in Moss that in camera review might deprive the litigating party of the opportunity to challenge the government's showing. Yet Congress overrode its concerns and passed the amendments, confident that the problems could be remedied. From the outset, Congress took the position in its deliberation on the FOIA amendments that ex parte proceedings should be the exception rather than the rule. ${ }^{102}$ Courts were to be encouraged to hear argument in open court or in chambers with both parties present; exclusion of the plaintiff's counsel was to occur only when his presence would itself pose a serious threat to national security. ${ }^{103}$ In cases necessitating ex parte presentations, Congress suggested that courts require the Government to file a memorandum, whenever possible, explaining its decision to withhold the material, thereby affording plaintiff's counsel an opportunity to respond. ${ }^{104}$ Whether these assurances and sug-

\footnotetext{
${ }^{97}$ See notes 22-34 supra and accompanying text.

98448 F.2d 1067 (D.C. Cir. 1971).

${ }^{99} \mathrm{Id}$. at $1079-80$.

${ }^{100}$ Civil No. 1254-71 (D.D.C., Dec. 7, 1971).

${ }^{101} \mathrm{Id}$. at 3. $C f$. Alderman v. United States, 394 U.S. 165 (1969).

${ }^{102}$ S. REP. No. 854, 93d Cong., 2d Sess. 14-15 (1974).

103120 Cong. REc. S9313 (daily ed. May 30, 1974) (remarks of Senator Kennedy).

${ }^{104}$ S. REp. No. 854, 93d Cong., 2d Sess. 14 (1974). See also Hearings on S. 1142 Before
} 
gestions of Congress will alleviate judicial fears of ex parte proceedings is a question that future litigation will resolve; but the courts should not attempt to avoid the problem by denying in camera inspection entirely.

The decision that offers the most helpful clue to how the courts will react to the FOIA amendments is Wolfe v. Froehlke. ${ }^{105}$ There the district court refused to order disclosure of contested documents, joint British-American files which the United States was willing to declassify though the United Kingdom was not. On appeal, the plaintiff asked the court to defer its decision pending enactment of the FOIA amendments. The court of appeals refused, declaring that "in camera review could add nothing relevant to the determination of this case." 106 Whether disclosure would indeed have been unwise under the circumstances is not important to decide here. What is significant is that the court rejected the opportunity to inspect the documents, even though it would have had the express statutory authority to do so had it deferred its decision for one month. The court's failure to analyze the Government's claim that foreign policy considerations precluded disclosure under the first exemption in light of the actual content of the files suggests that minimal in camera inspection is the path courts may choose to follow in the future.

Before concluding, however, that the FOIA amendments will have no effect on the judicial attitude toward national security classification cases, it must be pointed out that in the four areas discussed above the courts did not have an explicit congressional mandate to become involved in executive decisionmaking. Given Congress' specific authorization of in camera review in the FOIA amendments, the courts should feel compelled to depart from their traditional deference to the Executive and exercise their own independent judgment when litigants allege improper classification.

\section{The Appropriateness of Judrcial Review}

The FOIA amendments embody Congress' explicit and unambiguous intent to involve the judiciary more intimately with agency decisions to invoke the national security exemption. The broad scope of review granted to the courts by the amendments marks a substantial departure from the traditional reluctance of

the Subcomm. on Administrative Practice and Procedure of the Senate Comm. on the Judiciary, 93d Cong., 1st Sess., pt. 2, at 108 (1974) [hereinafter cited as Senate Hearings].

${ }^{105}$ Civil No. $73-1913$ (D.C. Cir., Oct. 23, 1974), aff'g 358 F. Supp. 1318 (D.D.C. 1973).

${ }^{106} I d$. at 3 . 
the judiciary to decide questions involving foreign affairs and national security. How appropriate is judicial review in this context? Since the Supreme Court's landmark decision in United States $v$. Curtiss-Wright Export Corp. ${ }^{107}$ the lower federal courts have accorded considerable deference to the Executive's conduct of foreign affairs. In Curtiss-Wright, the Court held that the President is "the sole organ of the federal government in the field of international relations." 108 The courts accordingly limited the scope of judicial review when foreign affairs questions were presented. ${ }^{109}$

The courts have traditionally invoked four principles to explain their reluctance to decide cases involving foreign affairs. First, certain legal issues are "political" rather than judicial, and are therefore better suited-constitutionally and practically-to resolution by one of the other branches of government. This is the "political question" doctrine. Second, courts argue that judicial proceedings would jeopardize the secrecy that is needed to conduct foreign relations. Third, courts reason that agencies, with their highly developed expertise, are well qualified to make foreign policy decisions and should be accorded a great deal of deference within their realm of expertise. Fourth, courts offer their own institutional infirmities and, in particular, their lack of expertise in foreign affairs, as a reason not to interfere.

The courts' reluctance to make decisions affecting foreign policy has left decisionmaking almost exclusively with administrative agencies. This Comment submits that examination of the four justifications reveals that a broader scope of review is called for.

\section{A. Political Question Analysis}

One way that courts have avoided foreign affairs issues is to treat them as political questions, beyond the scope of judicial

107299 U.S. 304 (1936).

${ }^{108} I d$. at 320.

${ }^{109}$ Id. at 319-22. Justice Sutherland analyzed the origin of presidential powers in foreign affairs in an historical context and concluded that the President's powers do not depend on an affirmative grant of authority from the Constitution. The Constitution carved out federal authority from that of the states; because the states never had international powers, these powers must have passed directly from the British Crown to the federal government when the colonies separated from England.

Justice Sutherland's analysis is criticized in Lofgren, United States v. Curtiss-Wright Export Corporation: An Historical Reassessment, 83 Y ALE L.J. 1 (1973). Professor Lofgren concludes: "If good history is a requisite to good constitutional law, then Curtiss-Wright ought to be relegated to history." Id. 32. See also Berger, The Presidential Monopoly of Foreign Relations, 71 Mrch. L. Rev. 1, 26-33 (1972). 
competence. In Chicago $\mathcal{E}$ Southern Air Lines, Inc. v. Waterman Steamship Corp. ${ }^{110}$ the Supreme Court held that

the very nature of executive decisions as to foreign policy is political, not judicial. . . . They are decisions of a kind for which the Judiciary has neither aptitude, facilities nor responsibility and which has long been held to belong in the domain of political power not subject to judicial intrusion or inquiry. ${ }^{111}$

Courts that have been requested to plunge into the thicket of national security issues frequently invoke the language and spirit of Waterman as a justification for non-involvement. ${ }^{112}$

The classic definition of a nonjusticiable political question comes from Baker $v$. Carr. ${ }^{113}$ There the Supreme Court, per Justice Brennan, set forth two principal rationales for judicial inaction. The first is that political questions lack satisfactory criteria to provide the basis for a judicial determination; the second is that "the nonjusticiability of a political question is primarily a function of the separation of powers."114 Neither of these two rationales, however, is applicable to foreign affairs issues under the FOIA as amended.

The absence of standards is not a problem under the amendments. The new legislation provides that the court must determine whether a document has in fact been properly classified according to the criteria established by executive order or statute. ${ }^{115}$ The criteria set forth, then, serve as a standard for the court. For example, Executive Order 11,652, promulgated by President Nixon, provides that " $[t]$ he test for assigning 'Top Secret' classification shall be whether its unauthorized disclosure could reasonably be expected to cause exceptionally grave damage to the national security." 116 The Order then lists five examples of what would constitute "exceptionally grave damage" and

110333 U.S. 103 (1948).

${ }^{111} I d$. at 111.

${ }^{112}$ E.g., Curran v. Laird, 420 F.2d 122, 129 (D.C. Cir. 1969); Harrington v. Schlesinger, 373 F. Supp. 1138, 1140 (E.D.N.C. 1974); see Oetjen v. Central Leather Co., 246 U.S. 297,302 (1918).

113369 U.S. 186 (1962).

${ }^{114}$ Id. at 210. Accord, Coleman v. Miller, 307 U.S. 433, 454-55 (1939): "In determining whether a question falls within [the political question] category, the appropriateness under our system of government of attributing finality to the action of the political departments and also the lack of satisfactory criteria for a judicial determination are dominant considerations."

115 Pub. L. No. 93-502 (Nov. 21, 1974), 88 Stat. 1561 (1974 U.S. Code Cong. \& Ad. News 5758), amending 5 U.S.C. $\$ 552$ (1970).

${ }^{116}$ Exec. Order No. 11,652, 3 C.F.R. 339 (1974). 
concludes with a caveat: "This classification shall be used with the utmost restraint." 117 Although this language is quite broad and leaves considerable room for discretion, it is nonetheless a standard to guide the court. ${ }^{118}$ Courts are frequently called upon to make discriminating decisions of comparable difficulty.

The political question issue came up during congressional debate over the FOIA amendments. Senator Hruska suggested that the issues that would arise under the amendments would raise the same sort of political problems as a case involving termination of a treaty, a classic example of the political question problem. The Senator stated that the decision whether classified documents should be disclosed is a political judgment requiring the consideration of on-going negotiations, timeliness, and the disclosure of other information. "Who is in a better position to make this judgment," the Senator inquired, "--the Secretary of State or a district judge?"119

The Senator's rhetorical question misses the point. Agencies admittedly have more experience and expertise in a particular area than courts. The role of the court is not to usurp the function of an agency head, but to weigh the strength of his arguments against those of the litigant requesting disclosure, to determine whether the former has properly exercised his authority under the relevant law.

Since the Waterman decision, courts have become more willing to examine questions implicating foreign affairs matters and to determine whether the Executive has exceeded his statutory authority. ${ }^{120}$ As the Supreme Court noted in Baker v. Carr:

There are sweeping statements to the effect that all questions touching foreign relations are political ques-

${ }^{117} I d .340$. The five examples are:

armed hostilities against the United States or its allies; disruption of foreign relations vitally affecting the national security; the compromise of vital national defense plans or complex cryptologic and communications intelligence systems; the revelation of sensitive intelligence operations; and the disclosure of scientific or technological developments vital to the national security.

Id. The order also provides standards for the other levels of classification.

${ }_{118}$ The order sets forth both substantive and procedural guidelines to direct the court in its inquiry. For example, the order forbids classification to conceal inefficiency or administrative error, or to prevent embarrassment to a person or department. Each classified document must indicate whether it is exempt from the automatic declassification schedule; it must show the office of origin and date of classification; and, to the extent possible, the document should be marked to indicate which of its parts are not classified. Id. 343.

119120 Cong. Rec. $S 9323$ (daily ed. May 30, 1974) (remarks of Senator Hruska).

${ }^{120}$ For a discussion of the erosion of the Waterman Doctrine, see Miller, The Waterman Doctrine Revisited, 54 Gro. L.J. 5 (1965). 
tions. . . . Yet it is error to suppose that every case or controversy which touches foreign relations lies beyond judicial cognizance. Our cases in this field seem invariably to show a discriminating analysis of the particular question posed, in terms of the history of its management by the political branches, of its susceptibility to judicial handling in the light of its nature and posture in the specific case, and of the possible consequences of judicial action. ${ }^{121}$

The second and more significant rationale for the political question doctrine is the separation of powers. The theory is that the Executive can only function effectively in an area like foreign affairs, committed to him by the Constitution, if he can operate undisturbed by the courts. For example, the power to recognize a foreign government ${ }^{122}$ or the authority to grant sovereign immunity ${ }^{123}$ belongs essentially to the executive branch.

It has been argued that the separation of powers doctrine limits judicial review of national security classifications as a matter of constitutional law. In his message explaining the veto of the FOIA amendments, President Ford said that the de novo review provision "would violate constitutional principles, and give less weight before the courts to an executive determination involving the protection of our most vital national defense interests than is accorded determinations involving routine regulatory matters."124 President Ford's position was that the decision to classify a document and withhold disclosure can be exercised properly only by the Chief Executive, because the Constitution vests in him the authority to conduct foreign relations and maintain the national defense. ${ }^{125}$

121369 U.S. 186, 211 (1962) (citation omitted).

${ }^{122}$ E.g., United States v. Pink, 315 U.S. 203, 230 (1942).

${ }^{123}$ E.g., Spacil v. Crowe, 489 F.2d 614, $617-18$ (5th Cir. 1974), in which the court observed: "Separation-of-powers principles impel a reluctance in the judiciary to interfere with or embarrass the executive in its constitutional role as the nation's primary organ of international policy." Id. at 619.

124 Veto Message, supra note 50. Although it is true that de novo review of the classification decision goes beyond the scope of review generally engaged in by a court in regulatory cases, the regulatory decisions are usually the product of hearings generously laden with procedural safeguards. The decision to classify a document may be made casually by a single government employee. For a discussion of the scope of review ordinarily applied by the courts in administrative cases, see Davis, Administrative Law TExr $§ 29$ (3d ed. 1972).

125 Senator Hruska supported the President's views during debate in Congress over whether to override the presidential veto. 120 Cong. REC. S19813 (daily ed. Nov. 21, 1974) (remarks of Senator Hruska). See Comment, Developments Under the Freedom of Information Act-1973, 1974 DukE L.J. 25 1, 258-59. 
The separation of powers doctrine, however, does not require that the Executive exercise unchecked power in the area of foreign affairs. The purpose of the doctrine is to preserve the integrity of the three branches of government and to ensure each branch's independence. ${ }^{126}$ It does not require absolute deference to the Executive's decisions when the Executive has decided to withhold a document that does not contain diplomatic or military secrets. ${ }^{127}$

The courts, as the President acknowledged, ${ }^{128}$ have some role to play in the classification system. The real issue, according to Professor Kurland, is the appropriate scope of that role. ${ }^{129}$ Congress, in enacting the FOIA amendments, determined that the Executive must be bound by his own criteria, that is, that documents must be properly classified in accordance with the applicable standards. The President believes that the classification must be upheld if the decision is merely reasonable. Both the President and Congress assume that judicial review is appropriate; they differ only on the standard of review. Professor Kurland concludes, "I do not see how it is possible to say that the Presidential position is constitutional but the Congressional position unconstitutional." 130 In both cases courts have the power to overrule the Executive.

Whether constitutionally compelled or not, the political question doctrine does not preclude review of classification decisions as authorized by the new legislation. The amendments provide enough safeguards and standards that judicial review of classification decisions will not impede the Executive in the discharge of his constitutional functions. The doctrine may not be constitutionally compelled at all, but rather a matter of judicial prudence. Even if based on the concept of separation of powers,

The precept that federal courts do not decide political questions does not arise ... from the text of the Constitution. . . . The political question doctrine limits the exercise, not the existence, of federal judicial power. Thus, even though a dispute may constitutionally be

${ }^{126}$ See Myers v. United States, 272 U.S. 52, 291-95 (1926) (Brandēis, J., dissenting).

${ }^{127}$ See Developments in the Law-The National Security Interest and Civil Liberties, 83 HARv. L. REv. 1130, 1219 (1972) [hereinafter cited as Developments-National Security]. Cf. Committee for Nuclear Responsibility, Inc. v. Seaborg, 463 F.2d 788, 793-94 (D.C. Cir. 1971).

${ }_{128}$ VETO MESSAGE, supra note 50.

${ }^{129}$ Letter from Philip B. Kurland to Senator Muskie, Nov. 15, 1974, in Cong. Rec. S19602 (daily ed. Nov. 19, 1974).

${ }^{130}$ Id. 603 . 
subject to the judicial power, if a political question is present, a federal court should decline to reach the merits. ${ }^{131}$

Courts often discuss impediments to deciding cases in terms of the political question analysis, but these impediments should not prevent review. The need for secrecy, agency expertise, and judicial incompetence in matters of foreign policy neither present political questions nor stand as practical barriers to judicial review of agency classification decisions.

\section{B. The Need for Secrecy in Foreign Affairs}

Secrecy is expressly provided for only once in the Constitution: ${ }^{132}$ Congress is authorized not to publish those portions of the journal of its proceedings that it determines must be kept secret. ${ }^{133}$ Nevertheless, secrecy has been invoked by the Executive throughout the nation's history as necessary to the proper fulfillment of the foreign affairs function. ${ }^{\mathbf{1 3 4}}$

The courts have recognized the need for executive secrecy in the conduct of foreign relations and the preservation of national defense and have declined to review executive decisions in these areas. ${ }^{135}$ In Spacil $v$. Crowe, ${ }^{136}$ the Court of Appeals for the Fifth Circuit refused to review, even for "reasonableness," the State Department's decision to grant sovereign immunity to Cuba in litigation between the Cuban government and a Chilean corporation. The Court remarked, "It is the legitimate role of secrecy in foreign relations which, more than any other factor, distinguishes executive decisions directly concerning foreign policy from other agency action and makes judicial review peculiarly inappropriate in the foreign instance."137 Although courts do not separate the need for secrecy from the Executive's need to function freely in the foreign affairs area, the problem of secrecy presents practical difficulties regardless of the presence or absence of a nonjusticiable political question. ${ }^{138}$ Certainly secrecy plays an important role in the conduct of foreign affairs.

${ }^{131}$ Atlee v. Laird, 347 F. Supp. 689, 701 (E.D. Pa. 1972), aff'd per curiam sub nom. Atlee v. Schlesinger, 411 U.S. 911 (1973).

132 Executive Classification, supra note 16 , at 3.

133 U.S. Const. art. I, \& 5, cl. 3.

${ }^{134}$ See EXecutive Classification, supra note 16 , at 3.

${ }^{135} C f$. United States v. Nixon, 418 U.S. 683, 710-11 (1974).

136489 F.2d 614 (5th Cir. 1974).

${ }^{137} I d$. at 620.

${ }^{138}$ See Developments-National Security, supra note 127, at 1215-17; cf. Committee for Nuclear Responsibility, Inc. v. Seaborg, 463 F.2d 788, 793-94 (D.C. Cir. 1971). 
Secrecy allows for minimal defense security; it encourages candor in foreign relations and permits flexibility in negotiations with foreign governments and expression of internal opposition without the fear of fragmenting government policy. Maintaining secrecy in government, however, imposes substantial costs on a democracy, which requires that citizens be educated in matters concerning the operation of their government. ${ }^{139}$ Withholding information vests unbridled control in the Executive, creates a credibility gap between government and the governed, and provides the Government with an opportunity to use "leaks" to disclose only as much information as it deems useful, even though partial disclosure may substantially distort the truth. ${ }^{140}$

The amendments to the FOIA attempt to balance these competing considerations. Information that would indeed compromise the nation's foreign plicy or defense will not be released, except to the courts for in camera review. All the amendments effectively do is to shift control of that balance away from the Executive, who may have a vested interest in the outcome, to the judiciary, which can independently judge the need for secrecy in any particular case.

\section{Agency Expertise}

The courts have recognized that the Executive has a special expertise in the area of foreign affairs and have tended to defer to his judgment in these sensitive areas. ${ }^{141}$ The agency classifying a document is likely to have a broad understanding of the significance of its decision in the larger context of a defense strategy or comprehensive foreign policy. ${ }^{142}$ The court will only have access to the particular data involved in the litigation. Ex-

${ }^{139}$ James Madison once wrote:

A popular Government, without popular information, or the means of acquiring it, is but a Prologue to a Farce or a Tragedy; or, perhaps both. Knowledge will forever govern ignorance: And a people who mean to be their own Governors, must arm themselves with the power which knowledge gives.

Letter from James Madison to W.T. Barry, Aug. 4, 1822, 9 Writings of James Madison 103 (Hunt ed. 1910), quoted in EPA v. Mink, 410 U.S. 73, 110-11 (1973) (Douglas, J., dissenting).

${ }^{140}$ For a general discussion of the costs and benefits of open government, see Franck \& Weisband, Executive Secrecy in Three Democracies: The Parameters of Reform in SECRECY IN Foreign Pourcy 3 (T. Franck \& E. Weisband eds. 1974). The problem of unauthorized leaks resulting from too much secrecy is discussed in Executive Classification, supra note 16 , at 16 .

${ }^{141}$ See generally notes 107-12 supra \& accompanying text.

${ }^{142}$ See, e.g., U.S. v. Marchetti, 466 F.2d 1309, 1318 (4th Cir.), cert. denied, 409 U.S. 1063 (1972). 
clusive reliance on the agency's decision, however, is unwise. ${ }^{143}$ According to a 1973 report by the House Committee on Government Operations, the security classification system has been subject to considerable abuse. ${ }^{144}$

First, the number of agency bureaucrats authorized to classify documents is overwhelming. It has been estimated that 55,000 federal employees have the authority to stamp a document "confidential"; more than 18,000 are authorized to use the "secret" stamp; and nearly 3,000 bureaucrats can classify a document "top secret."145 Thousands of government employees, each familiar with only a small part of a broad national strategy or policy, are authorized to classify documents and remove them from public inspection. A federal judge is no less capable of perceiving broader issues than an intermediate-level agency employee working on a narrow aspect of a complex problem. At least the judge can require the agency to submit an explanation for the classification decision.

A second problem with the security classification system is the enormous number of documents that have been classified over the years. Although no one can give a precise count, some estimates have been startling. The Department of Defense alone, according to one expert, may have more than twenty million classified documents in its files, ${ }^{146}$ which are estimated to take up seventeen percent of the six million cubic feet of active Pentagon file space. ${ }^{147}$ That there are so many classified documents does not in itself imply abuse. It suggests, however, that classification is not reserved for the most definitively sensitive cases. Agency experts agree that many classified documents could be disclosed now without compromising national defense. ${ }^{148}$

Classification experts have offered examples of the overclas-

${ }^{143}$ See EPA v. Mink, 410 U.S. at $94-95$ (Stewart, J., concurring).

144 The scope of the problem is set forth in Executive Classification, supra note 16 , at $32-51$.

145 Id. 33.

${ }^{146} I d .34-35$.

${ }^{147}$ Id. 35. Congressman Ogden Reid has calculated that the number of documents classified by the Defense Department "equals 18 stacks of documents 555 feet high, each as high as the Washington Monument." Id. 36.

The National Archives estimates that for the period from the beginning of the Second World War through the end of the Korean War it has in its possession approximately $\mathbf{4 7 0}$ million pages of classified documents. A substantial number of documents have been classified since the Korean War but have not yet been delivered to the Archives, so this half-billion-page figure largely underestimates the total number of documents classified to date. Id. 37.

${ }_{148}$ One Defense Department expert said that in his opinion disclosure of more than $99 \%$ of the classified documents would not jeopardize national defense. Id. 34 . 
sification phenomenon. When one of the Chiefs of Staff wrote a memorandum suggesting that use of the "top secret" classification stamp be reduced, the memorandum itself was stamped "top secret" by the Pentagon, as if to bear him out. ${ }^{149}$ Frequently the military classifies collections of documents, none of which would be classified if published separately. Such classification is explained by the following kind of statement: "Each section of this volume is in itself unclassified. to [sic] protect the compilation of information contained in the complete volume, the complete volume is confidential." 150

The FOIA amendments are designed to correct these kinds of classification abuses. Unless a judge is given the power to review the documents and the justification for the classification, overclassification passes unnoticed. If 55,000 bureaucrats can be trusted not to disclose confidential information, so can the federal judiciary.

\section{Judicial Competence}

In Curran v. Laird, the Court of Appeals for the District of Columbia Circuit held that the judiciary had neither the "aptitude, facilities, nor responsibility" to review foreign affairs questions. ${ }^{151}$ It has long been argued that courts are not equipped to resolve the complex issues that arise in the foreign affairs area. President Ford expressed these concerns in his veto message. ${ }^{152}$

Congress was aware of the lack of judicial expertise in the foreign affairs area when it passed the FOIA amendments, ${ }^{153}$ but it did not find the problem insurmountable. ${ }^{154}$ The Senate Judiciary Committee specifically concluded:

The judgments involved may often be delicate and difficult ones, but someone other than interested parties-officials with power to classify and conceal information-must be empowered to make them. It is

${ }^{149} I d$. 46. Other examples of less than discriminating use of classification authority included the classification of newspaper articles, generally available research studies, and Russian history lessons taught to Air Force trainees.

${ }^{150}$ Id. 48.

151420 F.2d 122, 129 (D.C. Cir. 1969) (quoting Chicago \& S. Air Lines v. Waterman Steamship Corp., 333 U.S. 103, 111 (1948)).

152 VETO MessaGe, supra note 50.

${ }^{153}$ Senator Kennedy asked several witnesses during the course of the Senate hearings whether they felt that the federal judiciary would be able to deal competently with the national security problems that would arise in cases challenging classification decisions. Senate Hearings, supra note 104.

${ }^{154}$ See text accompanying note 52 supra. 
the committee's conclusion that the courts are qualified to make such judgments. ${ }^{155}$

The committee suggested that courts make use of special masters or expert consultants to aid them in making what may often be sophisticated determinations. ${ }^{156}$

Courts are frequently called upon to make difficult judgments on complex subjects. ${ }^{157}$ With no special expertise in economics, physics, or engineering, courts resolve intricate factual disputes in antitrust, environmental, and patent cases. They can perform the same function when foreign affairs issues are raised in classification cases. A court is not being asked to determine the wisdom of granting sovereign immunity or of recognizing a foreign government. Rather, the court is required only to examine the executive decision in terms of the Executive's own criteria. ${ }^{158}$

\section{E. Summary: The Need for Judicial Review}

The standard objections to anything but the most limited judicial review do not render review under the FOIA amendments inappropriate. Although the amendments expand the traditional role of the courts in the area of foreign affairs, the courts should be able to meet the challenge. The relevant executive orders set forth standards to guide the courts; actual need for secrecy will not be compromised; agency expertise will prevail when the agency explains its position to the court; and judges will develop their own expertise in handling these matters as they have in other complex areas of litigation.

\section{Conclusion: The Rising Dissent}

"Security," Justice Jackson once wrote, "is like liberty in that many are the crimes committed in its name." ${ }^{159}$ National security has been used too readily to thwart judicial examination of executive decisions, and Justice Jackson is not alone in his recogni-

155 S. Rep. No. 854, 93d Cong., 2d Sess. 31 (1974).

${ }^{156}$ Id. But see Committee for Nuclear Responsibility, Inc. v. Seaborg, 463 F.2d 788, 794-95 n.12 (D.C. Cir. 1971), where the court suggested the use of a governmentappointed expert to aid the judge in analyzing the documents. See also Vaughn v. Rosen, 484 F.2d 820, 828 (D.C. Cir. 1973), cert. denied, 415 U.S. 977 (1974), noted in 122

U. PA. L. REv. 731 (1974).

${ }^{157}$ See generally Developments-National Security, supra note 127, at 1225.

${ }^{158}$ See note 115 supra \& accompanying text.

${ }^{159}$ United States ex rel. Knauff v. Shaughnessy, 338 U.S. 537, 551 (1950) (Jackson, J., dissenting). 
tion of the abuses to which the national security label has been subjected.

The deference traditionally accorded by courts to the Executive in national security matters has prompted a consistent series of lively dissents. Congress clearly feels that the time has come to adopt what has historically been the dissenting position and to encourage courts to assume a more vigorous role in foreign affairs issues, specifically with regard to the declassification of national security documents. To predict how the courts will respond to the FOIA amendments is difficult, as the courts are afforded a considerable amount of discretion in the use of their new powers. Some executive agencies seem to sense that the new legislation will have a substantial impact on their ability to withhold information. Shortly after passage of the FOIA amendments, for example, high officials in the Central Intelligence Agency tried to destroy controversial documents which they feared could now be seen by the public. ${ }^{160}$

Recent events have engendered a growing concern about covert national security operations conducted by FBI, CIA, and White House operatives. Congressional committees and blue ribbon commissions have assumed responsibility for unraveling the complex threads of foreign and domestic intelligence operations. ${ }^{161}$ Congress, by enacting the FOIA amendments over a presidential veto, has determined that the courts, too, should play a role.

The courts can provide a useful forum for examining some of the issues raised by national security claims. Judges, insulated from political pressures and forces, can serve as impartial arbiters of government claims and public demands. To the extent that disclosure of government documents will not jeopardize the national security, the adversary system can serve as a valuable tool for determining the validity of government claims.

Although the courts have never shown an inclination to involve themselves with national security issues, the courts have never had a specific mandate such as the one in the FOIA amendments. The mandate comes at a timely moment in history, as the nation reevaluates presidential power in the aftermath of Watergate and public concern begins to focus on the federal government's national security apparatus. If the courts rise to the challenge, they will play an important role in protecting the national security without sacrificing the public's right to know.

${ }^{160}$ N.Y. Times, Jan. 10, 1975, at 1, col. 1.

${ }^{161}$ N.Y. Times, Jan. 12, 1975, § 4, at 1, col. 1; N.Y. Times, Jan. 21, 1975, at 1, col. 1. 